Article

\title{
Pyrolysis Recovery of Waste Shipping Oil Using Microwave Heating
}

\author{
Wan Adibah Wan Mahari ${ }^{1}$, Nur Fatihah Zainuddin ${ }^{1}$, Wan Mohd Norsani Wan Nik ${ }^{1}$, \\ Cheng Tung Chong ${ }^{2}$ and Su Shiung Lam ${ }^{1, *}$ \\ 1 Eastern Corridor Renewable Energy Group (ECRE), School of Ocean Engineering, \\ Universiti Malaysia Terengganu, 21030 Kuala Terengganu, Terengganu, Malaysia; \\ adibah.mahari@gmail.com (W.A.W.M.); nurfatihah0406@gmail.com (N.F.Z.); \\ niksani@umt.edu.my (W.M.N.W.N.) \\ 2 Faculty of Mechanical Engineering, Universiti Teknologi Malaysia, 81310 Skudai, Johor, Malaysia; \\ ctchong@mail.fkm.utm.my \\ * Correspondence: lam@umt.edu.my; Tel.: +60-9-668-3844; Fax: +60-9-668-3991
}

Academic Editor: Ola Eriksson

Received: 2 August 2016; Accepted: 14 September 2016; Published: 27 September 2016

\begin{abstract}
This study investigated the use of microwave pyrolysis as a recovery method for waste shipping oil. The influence of different process temperatures on the yield and composition of the pyrolysis products was investigated. The use of microwave heating provided a fast heating rate $\left(40{ }^{\circ} \mathrm{C} / \mathrm{min}\right.$ ) to heat the waste oil at $600^{\circ} \mathrm{C}$. The waste oil was pyrolyzed and decomposed to form products dominated by pyrolysis oil (up to $66 \mathrm{wt}$. \%) and smaller amounts of pyrolysis gases (24 wt. \%) and char residue (10 wt. \%). The pyrolysis oil contained light $\mathrm{C}_{9}-\mathrm{C}_{30}$ hydrocarbons and was detected to have a calorific value of $47-48 \mathrm{MJ} / \mathrm{kg}$ which is close to those traditional liquid fuels derived from fossil fuel. The results show that microwave pyrolysis of waste shipping oil generated an oil product that could be used as a potential fuel.
\end{abstract}

Keywords: pyrolysis; microwave pyrolysis; microwave; waste oil; ship oil

\section{Introduction}

Maritime activities such as fishing activities and shipping operations for the transportation of bulk containers, passengers, and trading of goods have had a tremendous effect on the economic sectors. It has been reported that more than $90 \%$ of global trade is carried out by shipping activities and the activities have been increasing each year worldwide [1]. Nevertheless, these activities have also caused environmental pollution to the sea and its ecosystem such as waste spillage, illegal oil discharge and toxic air emissions. It has been estimated that approximately $51 \%$ of oil pollution in the marine environment is derived from the illegal or inappropriate discharge of oily wastes from shipping activities [2]. Furthermore, oil pollution has been reported to be responsible for the death of more than 20,000 birds, millions of benthic species, sea urchins, mollusks, and fin fisheries [3]. Oil pollution has also been reported to contribute to the loss and damage of habitat (i.e., mangrove forests) in the Caribbean Sea ecosystem [2]. Thus, efforts have to be made to conserve the marine biodiversity and overcome these environmental obstacles.

Oil pollution from shipping activities can be derived from a few sources which are waste shipping oil, bilge water, and oil sludge [1,2]. Among these oil sources, waste shipping oil, the lubricating oil used in ship engine operation, can cause the most devastating effect due to its high concentration of potentially hazardous compounds such as polycyclic aromatic hydrocarbon (PAH), metals, and soot. The shipping oil is important to safeguard the engine operation in the ships because it prevents corrosion between the moving parts in the engine. After certain period of usage, the oil gradually 
degrades and loses its function [4] and then becomes physically and chemically unsuitable for further use, thus transforming into a waste shipping oil that must be disposed of.

The common disposal method for waste shipping oil is to collect and incinerate the oil onboard, transfer the waste oil to a waste receiving facility at a port, followed by treatment with mechanical separation technology, or the waste oil is simply discharged into the ocean. On account of the additional management and the transportation cost needed for the disposal of the waste oil, the illegal dumping of waste oil into the ocean could be the normal practice of irresponsible parties including unsupervised government authorities. These existing disposal processes are either not environmentally friendly or are becoming increasingly impractical due to concerns over greenhouse gas release from incineration, the presence of undesirable contaminants that cannot simply be treated by mechanical means, and the environmental pollution resulting from discharging into the ocean.

Microwave pyrolysis has been explored as a promising technique to convert waste materials to produce potentially useful pyrolysis products [5-10]. It is a thermochemical conversion method performed in an inert atmosphere from which oxygen is excluded to produce liquid oil, gases and char product. The liquid oil and gases could be used as fuel for power generation as they are reported to have a high energy content [11], whereas the char product could be used as activated carbon. Microwave pyrolysis allows accurate and controlled heating since the process can be turned on and off instantly [12]. In addition, microwave pyrolysis shows a major advantage in facilitating rapid and efficient heating compared to conventional pyrolysis techniques in which the materials can be rapidly heated to achieve a high temperature within a few minutes $[13,14]$. Thus, this pyrolysis approach shows the potential to increase the production rate, generate products of better quality, reduce undesired secondary reactions and save energy $[8,15]$. The foremost reactions happening throughout the microwave pyrolysis of waste oil have been explained in detail in aforementioned works [15-17]. There are two stages of pyrolysis that can occur during microwave pyrolysis, namely the primary and secondary pyrolysis stages. In the primary pyrolysis stage, waste material is transformed into volatiles that could leave the reactor as pyrolysis gases or condensed into oil products. The volatiles are comprised of gaseous hydrocarbons, light hydrocarbons $\left(<\mathrm{C}_{25}\right)$ and permanent gases such as $\mathrm{CO}$ and $\mathrm{H}_{2}$. In the secondary pyrolysis stage, enhanced cracking and heterogeneous reactions could occur to produce lighter gaseous hydrocarbons $\left(C_{1}-C_{4}\right)$, liquid oil hydrocarbons $\left(<C_{18}\right)$ and some other gas species [10]. In addition, various types of reactions such as deoxygenation, aromatization, dehydrogenation and reforming could occur and influence the product yield and compositions.

The above findings provided the motivation for this study, which is to investigate the feasibility of microwave pyrolysis to treat and recover potentially useful products from waste shipping oil. The influence of different process temperatures on the yield and composition of the pyrolysis products was investigated.

\section{Methods}

\subsection{Materials}

Waste shipping oil was collected from the diesel engine of fishing boats operating at South China Sea along the East Coast of Malaysia. Before pyrolysis, the waste oil was filtered through a $100 \mu \mathrm{m}$ filter in order to remove metal particles, carbon soot and other scums so that the remaining particulates were less than $100 \mu \mathrm{m}$. The oil sample was then heated at $110^{\circ} \mathrm{C}$ to eliminate any volatiles and water content. Activated carbon with a size ranging from 0.1 to $0.5 \mathrm{~cm}$ was used as a microwave absorbent to absorb the microwave radiation for conversion into heat to pyrolyze the waste oil.

\subsection{Experimental Details on Microwave Pyrolysis of Waste Shipping Oil}

A $1 \mathrm{~kW}$ microwave oven was used to perform the pyrolysis of waste shipping oil in a semi-continuous batch operation as shown in Figure 1. A cylindrical-shape quartz reactor of $100 \mathrm{~mm}$ length and $120 \mathrm{~mm}$ diameter was used and the reactor was placed into the center of the 
microwave oven. Activated carbon was used the microwave absorbent to facilitate the heating process to achieve pyrolytic thermal cracking of the waste oil. The absorbent was placed into the reactor in one batch in a ratio of 4:1 wt./wt. of absorbents to sample (50 g). The apparatus was assembled as shown in Figure 1. Nitrogen gas was purged at a flow rate of $200 \mathrm{~mL} / \mathrm{min}$ to maintain the apparatus in an inert atmosphere. A complete purge of air was ensured by washing out the system for at least $10 \mathrm{~min}$ by $\mathrm{N}_{2}$ gas before heating. The temperature was monitored using Type-K thermocouple that is inserted into the middle layer of the carbon bed. The thermocouple probe is in direct contact with both the waste shipping oil and the activated carbon in the reactor during the pyrolysis experiment. The temperature measured using thermocouple was also validated with the use of an infrared red thermometer, and the results of validation showed good precision with low standard deviations shown in the recorded temperature $\left( \pm 1-3^{\circ} \mathrm{C}\right)$. In addition, the magnetrons of the microwave oven are controlled by an electronic temperature controller that maintains the temperature at the set point within a user-specified tolerance by switching the magnetrons on and off appropriately.

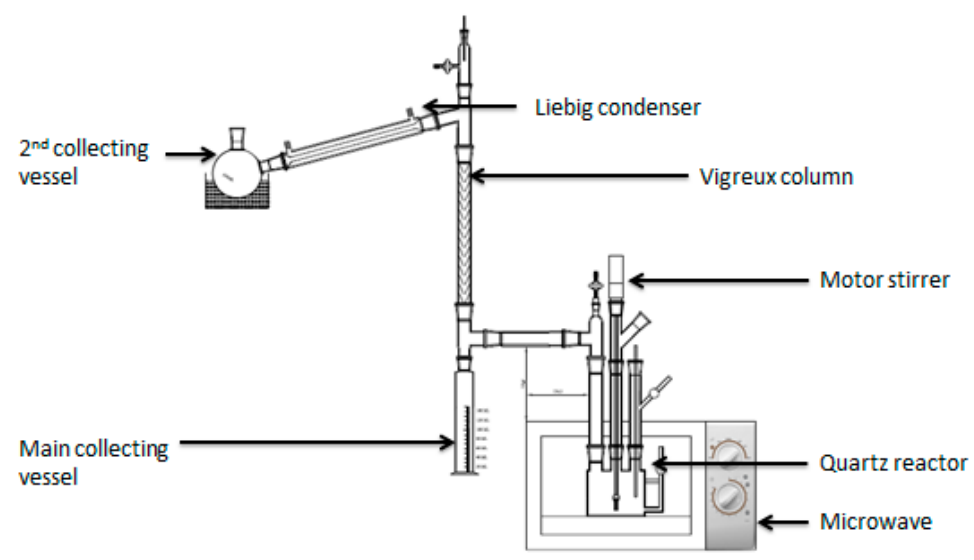

Figure 1. Schematic diagram of microwave pyrolysis apparatus.

The oil was heated from room temperature to target temperatures ranging from 300 to $600{ }^{\circ} \mathrm{C}$. Both the waste oil and the absorbent were homogenously mixed by a stirrer to ensure uniform heat distribution during the pyrolysis process.. The volatile products generated in the pyrolysis reaction left the reactor and passed through a condensation system and either condensed into pyrolysis oil or were collected as incondensable pyrolysis gases which can be sampled before being vented from the system, whereas the non-volatile char products were collected after the reactor was cooled to the room temperature.

The yield of pyrolysis oil was calculated from addition of the weight of the collecting vessels after the pyrolysis process, and the amount of the char product was determined by measuring the weight change in the reactor and its contents before and after the process. The gas yield was determined by calculating the mass difference. All the pyrolysis experiments were repeated three times to ensure good reproducibility of the data. Data analyses were performed using the Statistical Package for the Social Sciences (SPSS) ver. 13.0 statistical package (SPSS Inc., Chicago, IL, USA) assuming statistical significance if $p<0.05$. Data are presented as averaged values [mean \pm Standard Deviation (SD)] and were subjected to one-way analysis of variance (ANOVA). Duncan's multiple range test was used to compare mean yields in order to identify significant differences.

\subsection{Analytical Methods}

\subsubsection{Elemental Analysis}

Elemental analysis of the waste oil and pyrolysis oil was performed using Vario Macro Cube Elementar analyzer (Langenselbold, Germany). The sample was burned at a temperature of $1000^{\circ} \mathrm{C}$ in 
flowing oxygen for $\mathrm{C}, \mathrm{H}, \mathrm{N}$ and $\mathrm{S}$ analysis in the analyzer. The gases released from the combustion $\left(\mathrm{CO}_{2}, \mathrm{H}_{2} \mathrm{O}, \mathrm{NO}_{x}\right.$ and $\left.\mathrm{SO}_{2}\right)$ were measured by selective IR detector. After corresponding absorption of these gases, the content of the remaining nitrogen was determined by thermal conductivity detection. The amount of oxygen was calculated by deducting the percentage of $\mathrm{C}, \mathrm{H}, \mathrm{N}$ and $\mathrm{S}$ from 100 .

\subsubsection{Hydrocarbon Content}

Oil samples were analyzed using a Shimadzu Gas Chromatography Mass Spectrometry (GCMS) QP2010 Ultra (Shimadzu Corporation, Kyoto, Japan) to identify the hydrocarbons present in the oils. The oil samples were dissolved in heptane and then injected into GCMS using a splitless injector maintained at $300^{\circ} \mathrm{C}$. Oven temperature was held at $50{ }^{\circ} \mathrm{C}$ for $15 \mathrm{~min}$ and the temperature was then ramped up to $300{ }^{\circ} \mathrm{C}$ at a heating rate of $5{ }^{\circ} \mathrm{C} / \mathrm{min}$. The temperature was then held at $300{ }^{\circ} \mathrm{C}$ for $5 \mathrm{~min}$. The detector oven was programmed at $300{ }^{\circ} \mathrm{C}$. Helium was used as the carrier gas. The separation was performed using a BP-5 MS capillary column $(30 \mathrm{~m}$ length $\times 0.25 \mathrm{~mm}$ diameter $\times 0.25 \mu \mathrm{m}$ film thickness) made from Scientific Glass Engineering (SGE) Analytical Science Pty. Ltd. (Sydney, Australia). Identification of hydrocarbon was performed by comparing their mass spectra to the mass spectra contained in the (National Institute of Standards and Technology (NIST) library in the Mass Spectral database.

\subsubsection{Calorific Value}

Samples weighing $0.3 \mathrm{~g}$ were burned using a Parr 1341 Plain Jacket Calorimeter (Parr Instrument, Moline, IL, USA). Oxygen was supplied to pressurize the bomb calorimeter. The energy released by the combustion was recorded and calculated from the temperature change within the calorimeter.

\section{Results and Discussion}

\subsection{Temperature Profile and Heating Performance During Microwave Pyrolysis of Waste Shipping Oil}

The temperature profile during microwave pyrolysis of waste shipping oil performed at different temperatures was demonstrated in Figure 2. The results showed that waste shipping oil can only be heated to $114{ }^{\circ} \mathrm{C}$ by microwave radiation in the absence of a microwave absorbent. Although little pyrolysis volatiles and water were observed in the condensation apparatus, no liquid products were collected after a long period of time $(\geq 1 \mathrm{~h})$. These results showed that waste shipping oil is a poor microwave receptor; thus, a microwave absorbent with a better capability of absorbing and converting microwave radiation into heat was required to heat the waste oil to achieve the desired target temperatures $\left(400-600^{\circ} \mathrm{C}\right)$.

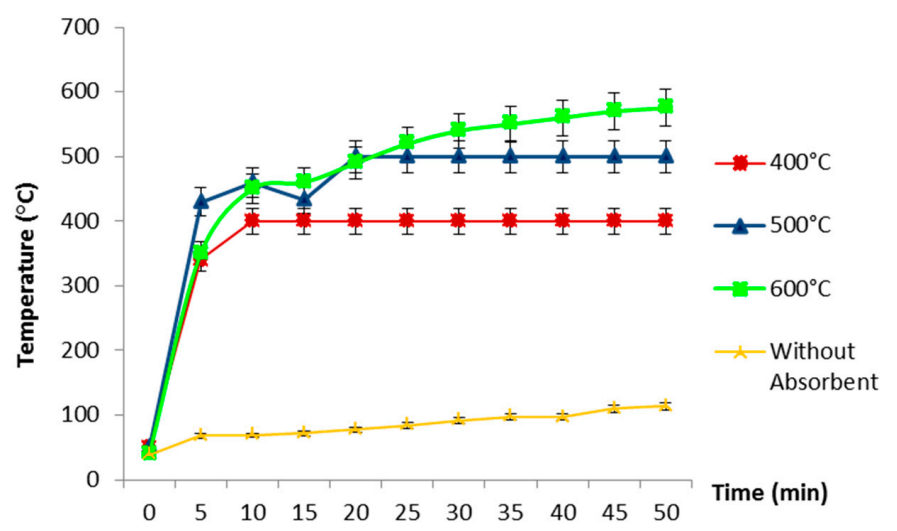

Figure 2. Temperature profiles of waste shipping oil during microwave pyrolysis at different temperatures. The data presented are means \pm SD of three valid runs $(N=3)$ where SD is indicated by the standard deviation bars. 
When waste shipping oil was mixed with activated carbon (acting as the microwave absorbent), a rapid heating process was observed where it only took $10 \mathrm{~min}$ to achieve $400{ }^{\circ} \mathrm{C}$, recording a heating rate of $40^{\circ} \mathrm{C} / \mathrm{min}$. This indicates the activated carbon shows great potential to be used as a microwave absorbent to convert microwave radiation to heat materials to a high temperature at a fast heating rate. In addition, the conversion of microwave energy into heat energy is associated with frictional resistance offered by the material in the electromagnetic microwave field. Kinetic energy associated with vibrational, rotational and translational movement of valence electrons is responsible for the generation of thermal energy. The excitement and movement of these valence electrons have resulted in the formation of arc plasma in which flashes of light were observed in the beginning of the heating process. This arc plasma formation was likely to have contributed to the fast heating rate during the pyrolysis process.

\subsection{Pyrolysis Product Distribution}

Figure 3 shows the product distribution obtained at different pyrolysis temperatures. At a lower temperature $\left(400^{\circ} \mathrm{C}\right)$, solid residues were produced in the highest yield ( $\left.59 \mathrm{wt} . \%\right)$, comprising a waxy mixture of unpyrolyzed waste oil and char residues. As the temperatures increased up to $600{ }^{\circ} \mathrm{C}$, the solid residues were decreased to $10 \mathrm{wt}$. \% whereas the liquid product showed an increment of $66 \mathrm{wt}$. \%. This could be attributed to the improved pyrolysis cracking of waste shipping oil to produce more pyrolysis volatiles that condensed into the oil product. The pyrolysis gases were increased up to $30 \mathrm{wt}$ \% when the temperature was increased up to $500{ }^{\circ} \mathrm{C}$, but the gases were decreased at $600{ }^{\circ} \mathrm{C}$. This could be due to the occurrence of secondary reactions such as aromatization that had converted some of the compounds in the pyrolysis gases into aromatics present in the liquid product, and also the carbonization that had produced char residue.

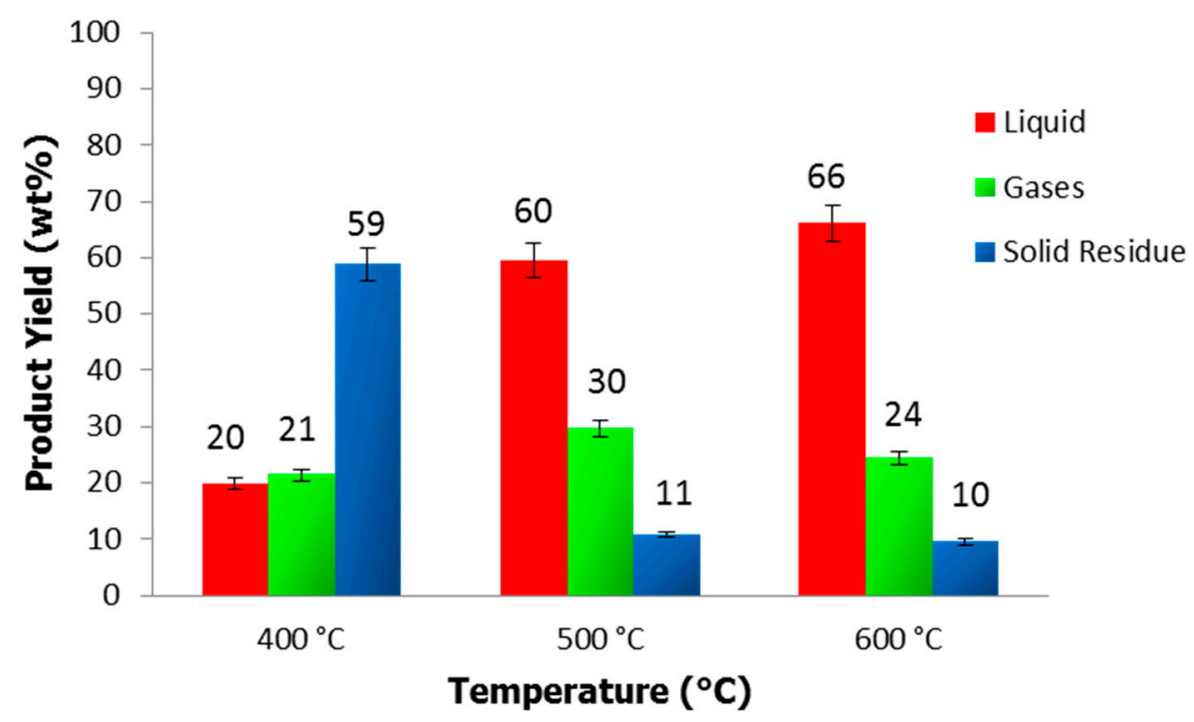

Figure 3. Product distribution. The data presented are means \pm Standard Deviation(SD) of three valid runs $(N=3)$ where SD is indicated by the standard deviation bars.

\subsection{Chemical Composition of Pyrolysis Oil}

Table 1 shows the chemical compositions of the original shipping oil (SO), the waste shipping oil (WSO), and the liquid pyrolysis oil obtained at different pyrolysis temperatures. Both the original (fresh) and waste shipping oil were composed a mixture of low- and high-molecular-weight aliphatic hydrocarbons. The original shipping oil was comprised primarily of $C_{16}-C_{45}$ hydrocarbons but the waste shipping oil was composed of lighter $\mathrm{C}_{11}-\mathrm{C}_{45}$ hydrocarbons, suggesting that a fraction of the heavier hydrocarbons originally present in the fresh shipping oil had been converted into lighter 
hydrocarbons during its use as a lubricant in the fuel engine [15], thus producing the waste shipping oil that contained a lighter hydrocarbon fraction.

Table 1 demonstrates that the compounds in the pyrolysis oil can be classified into several groups which are alkanes, alkenes, cycloalkanes, PAH and compounds unidentified by the GCMS. The liquid oil product was comprised of $\mathrm{C}_{9}-\mathrm{C}_{30}$ hydrocarbons which were dominated by aliphatic hydrocarbons $(40 \%-92 \%)$ and aromatics (2\%-19\%). The aliphatic hydrocarbons were mostly alkanes $(41 \%-92 \%)$, alkenes $(5 \%-18 \%)$, and cycloalkanes $(2 \%-4 \%)$, showing potential to be used as a fuel or chemical feedstock. The alkanes could be upgraded to produce transport-grade fuels, or gasified to commercially valuable gaseous products including hydrogen, whereas the alkenes are highly desired feedstocks in the petrochemical industry, especially in plastic manufacturing. The alkanes in the pyrolysis oil were found to decrease with the increase of the pyrolysis temperature. This could be accounted for by the increased occurrence of secondary reactions such as dehydration, aromatization and decarboxylation at higher temperatures during the pyrolysis process, converting the alkanes into alkenes or aromatic compounds $[10,18]$.

Table 1. Chemical compositions of original shipping oil (SO), waste shipping oil (WSO), and liquid pyrolysis oil obtained at different pyrolysis temperatures.

\begin{tabular}{|c|c|c|c|c|c|}
\hline \multirow{2}{*}{ Chemical Compositions } & \multirow{2}{*}{$\mathrm{SO}^{\mathrm{a}}$} & \multirow{2}{*}{ WSO $^{a}$} & \multicolumn{3}{|c|}{ Pyrolysis Oil $^{\text {a }}$} \\
\hline & & & $400{ }^{\circ} \mathrm{C}$ & $500{ }^{\circ} \mathrm{C}$ & $600{ }^{\circ} \mathrm{C}$ \\
\hline Alkanes & 72 & 81 & 92 & 89 & 88 \\
\hline Cycloalkanes & $-b$ & 0.81 & - & - & - \\
\hline Alkenes & 9 & 5 & 5 & 8 & 6 \\
\hline Total & 81 & 87 & 97 & 97 & 94 \\
\hline \multicolumn{6}{|l|}{ Carbon Compounds } \\
\hline $\mathrm{C}_{5}-\mathrm{C}_{10}$ & - & - & 24 & 39 & 27 \\
\hline $\mathrm{C}_{11}-\mathrm{C}_{15}$ & - & 5 & 62 & 37 & 35 \\
\hline $\mathrm{C}_{16}-\mathrm{C}_{20}$ & 12 & 42 & 11 & 21 & 30 \\
\hline $\mathrm{C}_{21}-\mathrm{C}_{30}$ & 42 & 27 & - & - & 2 \\
\hline $\mathrm{C}_{31}-\mathrm{C}_{45}$ & 27 & 13 & - & - & - \\
\hline \multicolumn{6}{|l|}{ PAH } \\
\hline Naphthalene & - & - & - & 1 & 2 \\
\hline Pyrene & - & - & 1 & - & - \\
\hline Anthracene & - & 4.88 & - & - & - \\
\hline
\end{tabular}

\subsection{Elemental Composition of Pyrolysis Oil}

The elemental compositions of the pyrolysis oil obtained at different process temperatures are shown in Table 2. Carbon and hydrogen were detected in high concentrations, while nitrogen, oxygen and sulphur showed a much lower concentration. The carbon content in pyrolysis oils was lower compared to the original shipping oil and waste shipping oil. This could be due to the secondary cracking reactions of hydrocarbons that occurred during the pyrolysis process, resulting in the production of light hydrocarbons present in gaseous form, which then escaped to the atmosphere with other paralysis gases. The sulphur content was detected in a higher concentration in the pyrolysis oils compared to the original and waste shipping oil. The higher concentration of sulphur in the pyrolysis oils was likely to have been derived from the sulphur remaining within the activated carbon that was used as the microwave absorbent. The sulphur from the activated carbon was likely to have vaporized and transferred to the pyrolysis oil from the cracking and heterogeneous reactions that occurred during the pyrolysis process at high temperatures. Additional treatment such as desulphurization can be performed if the complete removal of sulphur content is desired. 
Table 2. Elemental analysis (wt. \%) of the original shipping oil (SO), waste shipping oil (WSO) and pyrolysis oil.

\begin{tabular}{cccccc}
\hline \multirow{2}{*}{ Elemental Analysis } & \multirow{2}{*}{ SO } & WSO & \multicolumn{3}{c}{ Pyrolysis Oil } \\
\cline { 5 - 6 } & & & $\mathbf{4 0 0}{ }^{\circ} \mathbf{C}$ & $\mathbf{5 0 0}{ }^{\circ} \mathbf{C}$ & $\mathbf{6 0 0}^{\circ} \mathbf{C}$ \\
\hline $\mathrm{C}(\%)$ & 84.5 & 84.3 & 82.4 & 83.3 & 82.8 \\
$\mathrm{H}(\%)$ & 14.4 & 13.6 & 14.6 & 14.7 & 14.7 \\
$\mathrm{~N}(\%)$ & 0.9 & 0.9 & 0.9 & 0.7 & 0.6 \\
$\mathrm{~S}(\%)$ & 0.09 & 0.13 & 0.45 & 0.33 & 0.37 \\
$\mathrm{O}(\%)$ & 0.12 & 1.08 & 1.49 & 0.91 & 1.58 \\
$\mathrm{H} / \mathrm{C}(\mathrm{mol} / \mathrm{mol})$ & 2.05 & 1.93 & 2.15 & 2.12 & 2.13 \\
$\mathrm{H} / \mathrm{O}(\mathrm{mol} / \mathrm{mol})$ & 1971 & 201 & 158 & 259 & 148 \\
$\mathrm{O} / \mathrm{C}(\mathrm{mol} / \mathrm{mol})$ & 0.001 & 0.01 & 0.01 & 0.01 & 0.01 \\
\hline
\end{tabular}

The oxygen content of the pyrolysis oil was also detected at a higher concentration than the original and waste shipping oils. This could be attributed to the occurrence of the oxidation of the pyrolysis oils during storage. The pyrolysis oils may contain undesirable compounds such as hydroperoxides that may catalyze undesired polymerization and undergo oxidation reactions during storage [15], resulting in the formation of oxygenated compounds that in turn increases the oxygen content of the oil product. Despite the slightly higher oxygen content of the pyrolysis oil, the oil product still presents a low $\mathrm{O} / \mathrm{C}$ atomic ratio $(0.01)$ comparable to that shown by the waste shipping oil. Hydrotreatment or catalytic upgrading or reforming of pyrolysis oil with catalysts (e.g., zeolite) can be performed as a further treatment if a complete removal of oxygen content is required to convert the pyrolysis oil into products for further use. The $\mathrm{H} / \mathrm{C}$ atomic ratios showed a desirable sign of the presence of high hydrocarbon compounds in the pyrolysis oil. The variation of $\mathrm{H} / \mathrm{C}$ atomic ratios as the temperature increased indicated that there were different lengths of the carbon chain and amounts of double bonds in the molecules.

\subsection{Calorific Value, Mass Yield and Energy Yield of Pyrolysis Oil}

The mass yield of the pyrolysis oil and its energy recovery from the feedstock (i.e., waste shipping oil) were calculated to determine the weight difference and estimate the energy output from the microwave pyrolysis of the waste shipping oil (Table 3). The mass yield and energy recovery are calculated based on the following formula:

Mass yield of pyrolysis oil $=($ Mass of pyrolysis oil $/$ Mass of waste shipping oil $) \times 100$

Energy recovery of pyrolysis oil from the feedstock $=[($ Mass yield $\times$ Product's calorific value $)$

$\times 100] /($ Mass of waste shipping oil $\times$ Waste shipping oil's calorific value)

Table 3. Calorific value, mass yield and energy recovery of pyrolysis oil at different pyrolysis temperatures.

\begin{tabular}{cccc}
\hline Temperatures & Calorific Value (MJ/kg) & $\begin{array}{c}\text { Mass Yield of } \\
\text { Pyrolysis Oil (\%) }\end{array}$ & $\begin{array}{c}\text { Energy Recovery of } \\
\text { Pyrolysis Oil (\%) }\end{array}$ \\
\hline $400^{\circ} \mathrm{C}$ & 43 & 20 & 19 \\
$500^{\circ} \mathrm{C}$ & 46 & 60 & 61 \\
$600^{\circ} \mathrm{C}$ & 45 & 66 & 66 \\
\hline
\end{tabular}

At a low process temperature $\left(400{ }^{\circ} \mathrm{C}\right)$, the mass and energy recovery of the pyrolysis oil were low $(19 \%-20 \%)$. The calorific value was also lower than the original waste shipping oil, which indicates low energy recovery from the waste shipping oil at a low pyrolysis temperature. However, the calorific value of the pyrolysis oil was increased at a higher pyrolysis temperatures $\left(500-600{ }^{\circ} \mathrm{C}\right)$, which also increased the mass and energy recovery of the pyrolysis oil. The calorific value of the pyrolysis 
oil is in the range of $47-48 \mathrm{MJ} / \mathrm{kg}$ which is close to the traditional liquid fuels derived from fossil fuel (36-48 MJ $/ \mathrm{kg}$ ) [15], indicating that pyrolysis oils with high combustion energy can be obtained by microwave pyrolysis. The results show that microwave pyrolysis of waste ship lubricating oil generated an oil product that could be used as a potential fuel.

\section{Conclusions}

Waste shipping oil can be converted into an oil product at a rapid heating process $\left(40^{\circ} \mathrm{C} / \mathrm{min}\right)$ via microwave pyrolysis. The highest production of pyrolysis oil was observed at a pyrolysis temperature of $600{ }^{\circ} \mathrm{C}$ (up to $66 \mathrm{wt}$. \%). Pyrolysis oil was comprised of $\mathrm{C}_{9}-\mathrm{C}_{30}$ hydrocarbons which shows the conversion of the heavier hydrocarbon fraction of the waste shipping oil $\left(\mathrm{C}_{11}-\mathrm{C}_{45}\right)$ into a lighter hydrocarbon fraction. The calorific value of the pyrolysis oil is in the range of $47-48 \mathrm{MJ} / \mathrm{kg}$ which is close to the traditional liquid fuels derived from fossil fuel $(36-48 \mathrm{MJ} / \mathrm{kg})$, indicating that pyrolysis oils with a high combustion energy can be obtained by microwave pyrolysis. The results show that microwave pyrolysis of waste shipping oil generated an oil product that could be used as a potential fuel.

Acknowledgments: The authors acknowledges the financial support by the Ministry of Science, Technology, and Innovation Malaysia (MOSTI), the Ministry of Higher Education Malaysia (MOHE), and the University Malaysia Terengganu for the conduct of the research under the E-Science fund (UMT/RMC/SF/13/52072(5), Vot No: 52072), the Fundamental Research Grant Scheme (Project No.: FRGS/1/2013/TK05/UMT/02/2, Vot No: 59296), and the Research Acculturation Grant Scheme (Project No.: RAGS/2012/UMT/TK07/3, Vot No.: 57085).

Author Contributions: Su Shiung Lam conceived and designed the experiments; Wan Adibah Wan Mahari and Nur Fatihah Zainuddin performed the experiments; Wan Adibah Wan Mahari and Nur Fatihah Zainuddin analyzed the data; Wan Mohd Norsani Wan Nik and Cheng Tung Chong contributed to product and chemical analysis; Wan Adibah Wan Mahari, Nur Fatihah Zainuddin and Su Shiung Lam wrote the paper.

Conflicts of Interest: The authors declare no conflict of interest.

\section{References}

1. IMO (International Maritime Organization), Maritime Knowledge Centre. International Shipping Facts and Figures-Information Resources on Trade, Safety, Security, Environment. 2012. Available online: http://www.imo.org/en/KnowledgeCentre/ShipsAndShippingFactsAndFigures/ Documents/International\%20Shipping\%20-\%20Facts\%20and\%20Figures.pdf (accessed on 25 July 2016).

2. Singh, A.; Asmath, H.; Chee, C.L.; Darsan, J. Potential oil spill risk from shipping and the implications for management in the Caribbean Sea. Mar. Pollut. Bull. 2015, 93, 217-227. [CrossRef] [PubMed]

3. Maritime Connectors, Tanker Incidents. 2013. Available online: http://maritime-connector.com/tankerincidents/ (accessed on 25 July 2016).

4. Tsai, W.-T. An analysis of used lubricant recycling, energy utilization and its environmental benefit in Taiwan. Energy 2011, 36, 4333-4339. [CrossRef]

5. Lam, S.S.; Liew, R.K.; Jusoh, A.; Chong, C.T.; Ani, F.N.; Chase, H.A. Progress in waste oil to sustainable energy, with emphasis on pyrolysis techniques. Renew. Sustain. Energy Rev. 2016, 53, 741-753. [CrossRef]

6. Huang, Y.-F.; Chiueh, P.-T.; Kuan, W.-H.; Lo, S.-L. Microwave pyrolysis of lignocellulosic biomass: Heating performance and reaction kinetics. Energy 2016, 100, 137-144. [CrossRef]

7. Salema, A.A.; Ani, F.N. Pyrolysis of oil palm empty fruit bunch biomass pellets using multimode microwave irradiation. Bioresour. Technol. 2012, 125, 102-107. [CrossRef] [PubMed]

8. Mushtaq, F.; Mat, R.; Ani, F.N. A review on microwave assisted pyrolysis of coal and biomass for fuel production. Renew. Sustain. Energy Rev. 2014, 39, 555-574. [CrossRef]

9. Lam, S.S.; Liew, R.K.; Lim, X.Y.; Ani, F.N.; Jusoh, A. Fruit waste as feedstock for recovery by pyrolysis technique. Int. Biodeterior. Biodegrad. 2016, 113, 325-333. [CrossRef]

10. Lam, S.S.; Liew, R.K.; Cheng, C.K.; Chase, H.A. Catalytic microwave pyrolysis of waste engine oil using metallic pyrolysis char. Appl. Catal. B Environ. 2015, 176-177, 601-617. [CrossRef]

11. Tripathi, M.; Sahu, J.N.; Ganesan, P. Effect of process parameters on production of biochar from biomass waste through pyrolysis: A review. Renew. Sustain. Energy Rev. 2016, 55, 467-481. [CrossRef] 
12. Yin, C. Microwave-assisted pyrolysis of biomass for liquid biofuels production. Bioresour. Technol. 2012, 120, 273-284. [CrossRef] [PubMed]

13. Undri, A.; Abou-Zaid, M.; Briens, C.; Berruti, F.; Rosi, L.; Bartoli, M.; Frediani, M.; Frediani, P. Bio-oil from pyrolysis of wood pellets using a microwave multimode oven and different microwave absorbers. Fuel 2015, 153, 464-482. [CrossRef]

14. Undri, A.; Rosi, L.; Frediani, M.; Frediani, P. Upgraded fuel from microwave assisted pyrolysis of waste tire. Fuel 2014, 115, 600-608. [CrossRef]

15. Lam, S.S.; Russell, A.D.; Lee, C.L.; Chase, H.A. Microwave-heated pyrolysis of waste automotive engine oil: Influence of operation parameters on the yield, composition, and fuel properties of pyrolysis oil. Fuel 2012, 92, 327-339. [CrossRef]

16. Lam, S.S.; Russell, A.D.; Chase, H.A. Microwave pyrolysis, a novel process for recycling waste automotive engine oil. Energy 2010, 35, 2985-2991. [CrossRef]

17. Lam, S.S.; Russell, A.D.; Chase, H.A. Pyrolysis Using Microwave Heating: A Sustainable Process for Recycling Used Car Engine Oil. Ind. Eng. Chem. Res. 2010, 49, 10845-10851. [CrossRef]

18. Mohamed, B.A.; Kim, C.S.; Ellis, N.; Bi, X. Microwave-assisted catalytic pyrolysis of switchgrass for improving bio-oil and biochar properties. Bioresour. Technol. 2016, 201, 121-132. [CrossRef] [PubMed]

(C) 2016 by the authors; licensee MDPI, Basel, Switzerland. This article is an open access article distributed under the terms and conditions of the Creative Commons Attribution (CC-BY) license (http://creativecommons.org/licenses/by/4.0/). 